\title{
Electrical subsystem of the low-power cogeneration plant with low-speed vehicle
}

\author{
Andrei Khitrov, Alexander Khitrov \\ Pskov State University, Electro mechanic Faculty. Address: Russian Federation, Pskov, Lenin \\ square, 2
}

\begin{abstract}
Nowadays diesel power plants form the basis of distributed power generation in Russia, but they have disadvantages. The alternative variant is cogeneration plant based on the rotary-vane machine. One of the types of such machines is the rotary-vane external combustion vehicle (engine) developed in Pskov State University.

Electrical subsystem of the plant requires its effective work to provide both start and generation modes. Development of such subsystem structure, employment of elements for links with other subsystems in the hierarchic control system is an actual task.

The paper considers structures of the electrical part of the plant, simulation and experiment results.
\end{abstract}

Keywords - rotary-vane external combustion engine, co-generation plant, autonomous electrical supply system, permanent magnet synchronous machine, power factor corrector.

\section{INTRODUCION}

Decision of problems related to electric supply reliability improvement is one of the strategic aims of Russian electrical energy industry [1]. For this purpose it is necessary to build different types of electrical low-power generating plants (distributed power generation) which includes renewable energy sources. According to energy strategic program of Russia (until 2030 year) small and renewable energy generation have to increase 4 times as a whole.

In many distributed electrical grids there are no power reserves, low-voltage networks are overloaded; thus it requires electric energy generation to be close to user. Mobile autonomous energy plants and electrical power generating sets are designed to solve this problem. Such plants will be in demand - in energy providing systems in remote regions, elimination of emergency situations causing loss of normal electric power - as a backup power supply systems in mobile energy plants, for use in housing and communal services, agriculture.

At the present time the most effective decentralized autonomous power supply system (APSS) is a diesel power station (DPS). Energy of the gases expansion is generated during combustion of ignited from compression diesel fuel in diesel internal combustion engine (DICE) and is converted by crank-and-rod mechanism into mechanical energy of crankshaft rotation. Output shaft of an engine is connected to the rotor of a synchronous generator. Together they make mechatronic motion module.

When DPS works at low loads, specific fuel consumption of expensive diesel fuel per $1 \mathrm{~kW}$ of electric power increases significantly. In addition longtime power station work on the loads below 25\% of the rated load leads to emergency modes (coking cylinder and reduced engine service life) [2]. Wellknown disadvantages of piston engines: vibrations, significant friction losses in piston and cylinder unit.
Another known disadvantage is that valve drive requires energy expenditure and reduces energy conversion efficiency. This negative attributes require a search of alternative variations. One of the alternative constructions is a rotary-vane engine (RVE) - low-speed vehicle [3].

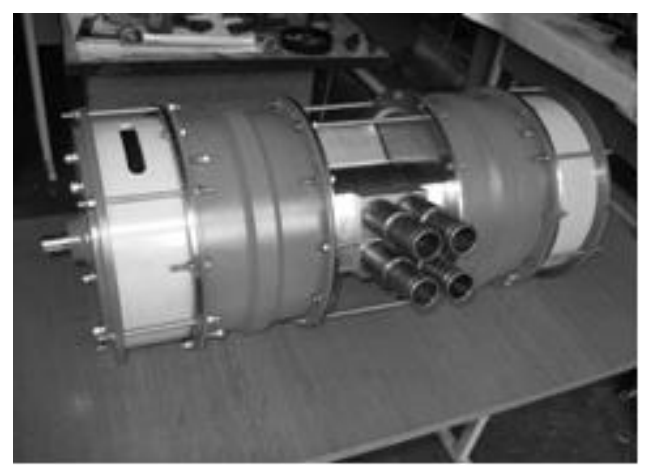

Fig. 1. Rotary-vane external combustion engine.

Developed (in Pskov State University) and patented design concepts for the rotary-vane external combustion engine (RVECE) of different electric power allowed at the present day to produce the development prototype which has a power of $1.5 \mathrm{~kW}$ [4] (Fig. 1).

RVECE falls into thermal energy converters; as distinct from DICE it can use more cheap resources as a source of thermal energy: natural gas and other types of fossil fuels as well as low-grade heat. Thermal energy conversion to the mechanical rotation of the RVECE shaft is performed by a specialized thermal cycle without a contact of cycle fluid and outside environment (ecological compatibility).

Currently developed in Pskov State University power plant is designed for autonomous use as a source of thermal and electric energy (cogeneration plant). In this paper details of the electrical part of a multi-level system are considered. 


\section{STARTER AND GENERATOR FOR ROTARY- VANE ENGINE WITH PERMANENT-MAGNET SYNCHRONOUS MOTOR}

Cogeneration plant control system (Fig. 2) based on the RVECE consists of top hierarchy level control module and three local subsystems: thermal energy control, control of torque and speed of the engine and electric energy control.

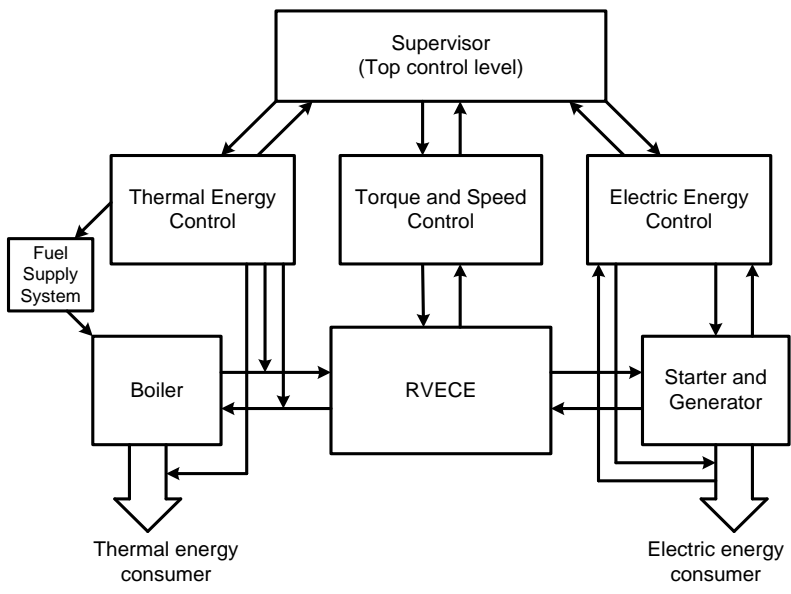

Fig. 2. Cogeneration plant control system

Consider electric energy control subsystem of the power plant with RVECE.

It is known that most of the APSS are realized by structures that provide either constant shaft rotation speed of the vehicle or variable speed with regulation of power through the electric parameters $[2,5]$.

The presence of external electric source (direct voltage or alternating voltage) is also possible in cogeneration plants. It allows ensuring the effective start modes of the RVECE. Economical run-up RVECE in it's start mode is allowed by use of brushless DC (direct current) motor (BLDC) permanent magnet synchronous motor (SMPM). In this case the unit must include recuperation module (active commutator - AFE (active front end converter)) and voltage inverter with the possibility to connect through the DC link.

Stabilization of the electrical part output parameters in system with the BLDC is usually provided by inverter of required power (voltage of the DC link in the range 450-600 V).

Shaft position sensor, indispensable component of the BLDC, in generator mode can provide organization of the shaft position and rotation speed signal in order to use in closed-loop control of thermomechanical subsystem in hierarchic control system of RVECE.

For running of the experiments to examine operating modes of BLDC (SMPM) as a starter and generator the test stand was created [6]. Stand uses the motor DVU2M165S (Fig. 3).

Tests have shown that in use of SMPM of DVU2M type (permanent magnets - strontium ferrites) working as a generator emf ratio is in the range $K_{E}=(0,6-3,0)$ $\mathrm{V} \cdot \mathrm{s} / \mathrm{rad}$.

The analysis and tests suggest it possible to use general-purpose SMPM as a starter-generator for RVECE in power plants with an output power from 1 $\mathrm{kW}$ to $20 \mathrm{~kW}$ [7].

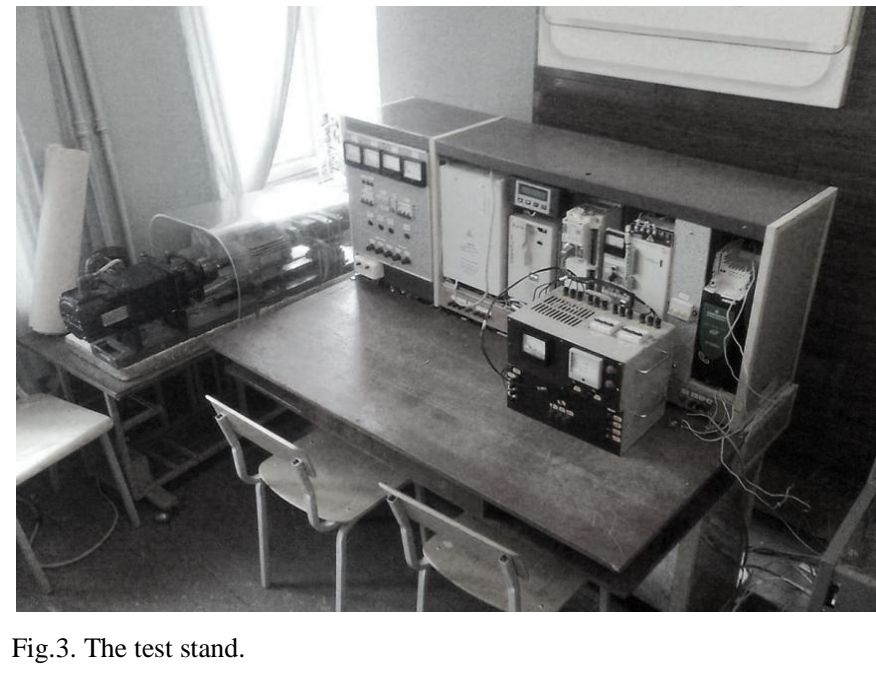

The most promising domestic (Russian industrial general-purpose motors) SMPM for APSS with RVECE starter-generator using are motors of 6DVM series with $\mathrm{Ne}-\mathrm{Fe}-\mathrm{B}$ permanent magnets.

In addition SMPM weight is in the range from 30 to $80 \mathrm{~kg}$ : that is considerably lower than mass and dimension parameters of traditional asynchronous and synchronous generators.

\section{ELECTRICAL SUBSYSTEM OF THE LOW- POWER PLANT WITH LOW-SPEED VEHICLE}

Fig. 4 shows the structure of the electrical subsystem of the plant for all necessary modes of operation:

- $\quad$ accumulator battery start $(\mathrm{AB})$;

- generator mode: one of the converters is active (AFE $(G)$ ), the second one inverter (INV $(\mathrm{G})$ );

- network start: commutators are swapped functionally (AFE(netwok) - INV(S));

- parallel operation with network.

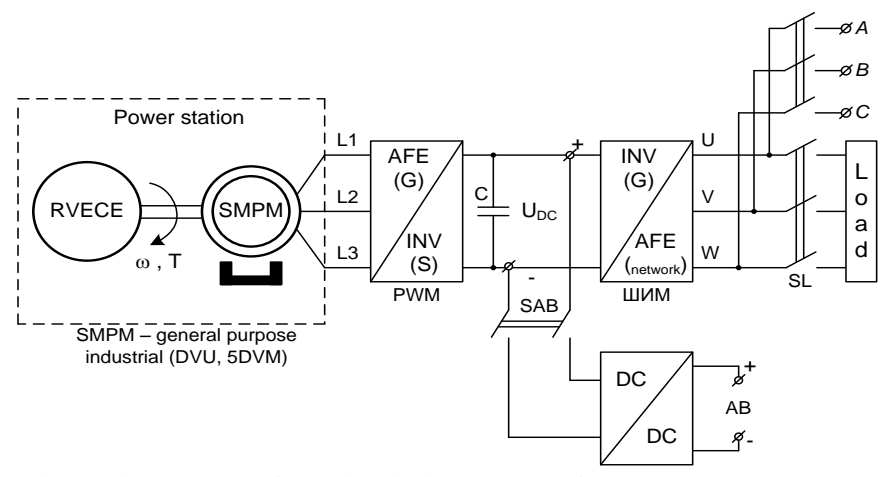

Fig. 4. The structure of the electrical subsystem of the autonomous power supply system based on rotary-vane external combustion engine. 
However, in creating APSS with SMPM for lowspeed RVECE $(<500 \mathrm{rpm})$ there is a need in multiplier of shaft speed or generator output voltage. Such device can be mechanical (reduction gear, Fig. 5a), electrical (step-up transformer, Fig. 5b) or electronic (DC/DC converter - power factor corrector (PFC), Fig. 5c).
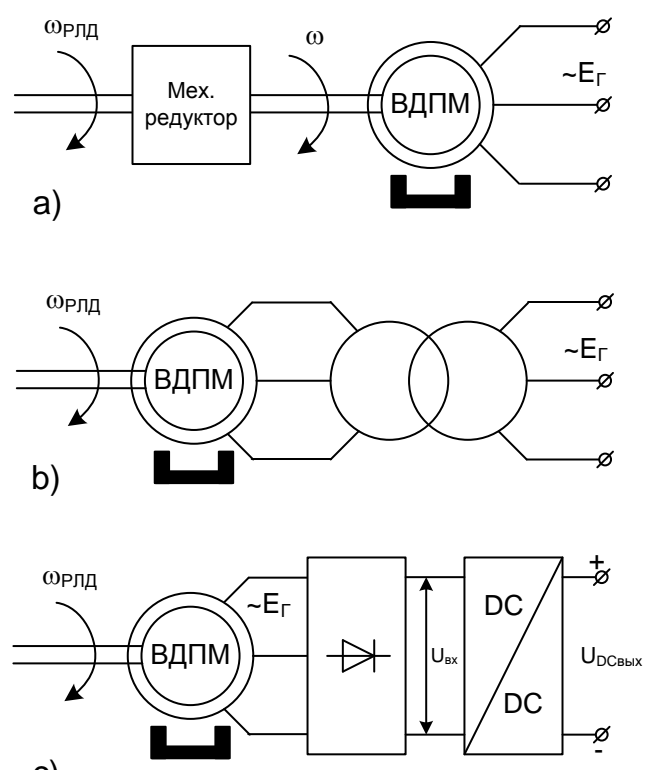

c)

Fig. 5. Different options of speed or output generator voltage multipliers.

Researches of the DVU working in generator mode based on the well-known structure with transformermultiplier were made - the results of the computer simulation and experiments of DVU2M165S in accordance with the functional diagram Fig. 6 are shown in the Fig. 7 (modeling was made using the program MATLAB Simulink). There are output voltage of the general-purpose SMPM confirming its ability to work as a generator (plus rectified voltage) and output voltage of the PWM-inverter. But the greater interest is in researches of structures with scheme $5 \mathrm{c}$ because of its controllability and thus the ability to influence the system parameters and embeddability in a general hierarchy of the plant control.

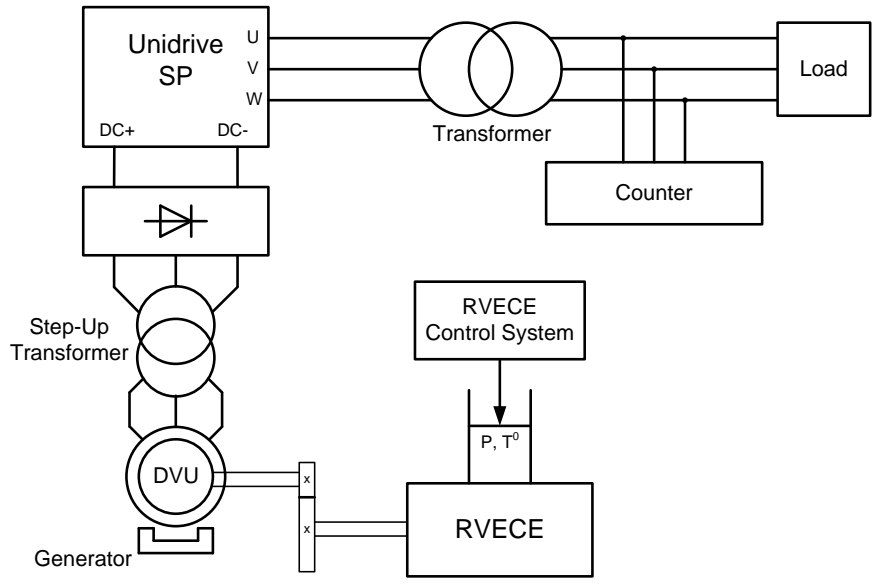

Fig. 6. The functional diagram of the experiments with electrical multiplier.
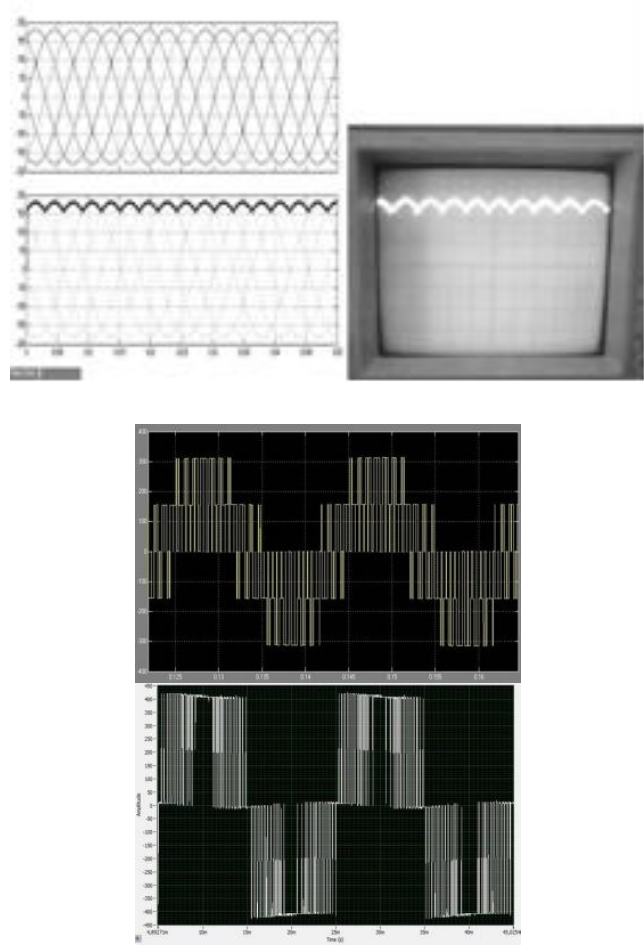

Fig. 7. Results of the simulation and experiments of DVU motor.

PFC is set between the output of a straight rectifier, and various non-linear loads, including power semiconductor converter. Single-and multi-phase PFC can be constructed on the basis of step-up pulse converter (Fig. 8).

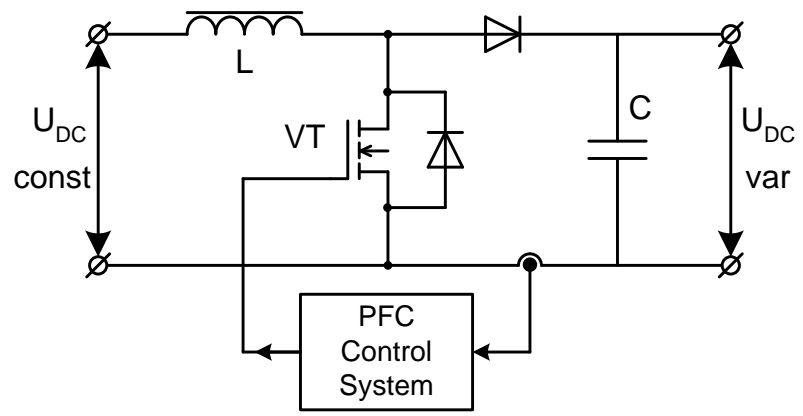

Fig. 8. PFC (DC/DC) module. 
In this case, the system takes the form similar structures applied in wind-driven plants for returning maximum electric power at any rotation speed, as shown in Fig. 9. This is so-called variable speed system, in which rectified voltage can be obtained either by AFE or conventional rectifier. The value of the output PFC voltage be a function of DC voltage or current, or load parameters (regulator R).

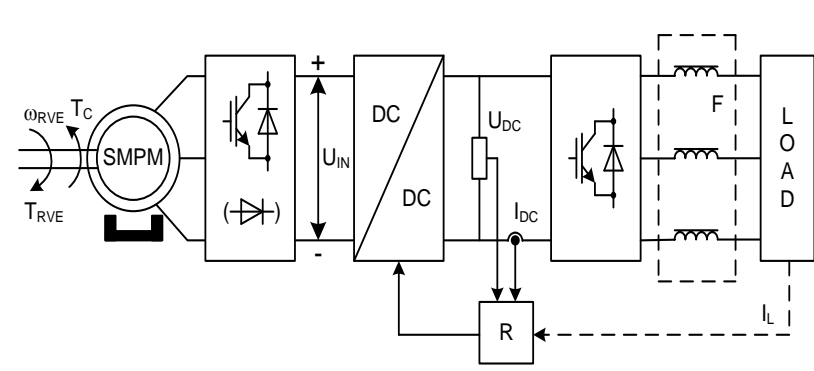

Fig. 9. The structure of the electric part with PFC-module.

Controlled DC-DC module allows providing amplitude regulation with constant output variable load voltage and current frequency; it increases the range of applied industrial inverters.

It was accepted that the DC-DC module provides the following law regulating the output voltage:

$$
\begin{gathered}
U_{d c}^{v a r}=U_{d c}^{\text {const }} \times \frac{1}{1-\gamma} \\
U_{d c}^{\text {const }}=\omega_{r v e}^{\text {const }} \times k_{e} \times k_{s c h},
\end{gathered}
$$

where $U_{d c}^{\text {const }}$ - output voltage of the three-phase straight rectifier, $U_{d c}^{v a r}$ - output voltage of the PFC module, $\gamma=\frac{t_{1}}{T}$ - on-state power transistor VT pulse duration to the full period (also including active power diode state), $\omega_{\text {rve }}^{\text {const }}-$ RVECE shaft speed, $k_{e}-$ emf transfer ratio, $k_{s c h}$ - coefficient of mechanical and electrical multiplexing scheme.

For accepted structure based on the DVU2M165S motor $\omega_{r v e}^{\text {const }}=104 \mathrm{rad} / \mathrm{s}, k_{e}=0,6, k_{s c h}=4,9$.

Construction of PFC control system can be performed in hardware or software. For a software implementation, there are two approaches - classic digital PID (PI) - controller, or the fuzzy logic regulation - fuzzy-controller. Fuzzy control does not require knowledge of the exact model of the object (which is currently under development), but it can organize an approximate control strategy.

Fig. 10 shows the simulation results when the load switching on in APSS with PFC; the diagrams of inverter output voltage, load current, output and input voltages of PFC and DC-current (obtained on the model of the structure Fig. 9) are sequentially presented.
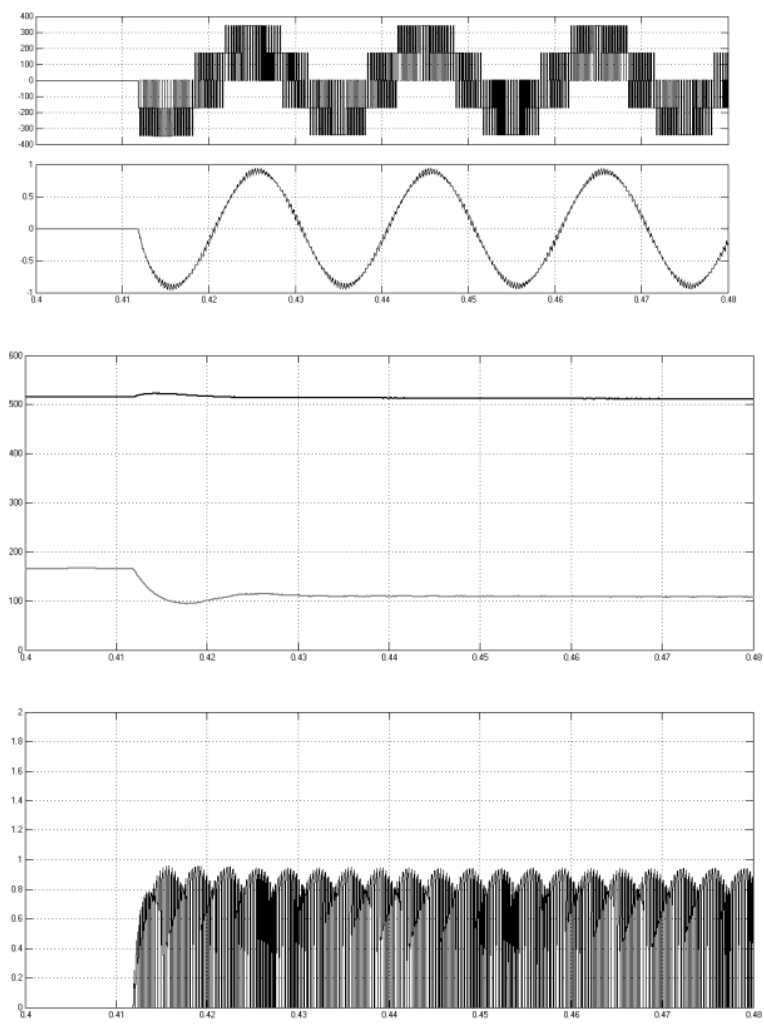

Fig. 10. The simulation results of the system with PFC.

\section{CONCLUSION}

The electrical part of the low-power $(<20 \mathrm{~kW})$ (2) power plant with low-speed rotary-vane engine (which is the setting for providing various modes of start and generation) can be implemented on typical industrial general-purpose BLDC (SMPM).

The structure of the electric subsystem for the APSS based on the RVECE providing efficient work in various modes is designed - structure with PFC module, considering features of rotary-vane engine shaft rotation. PFC control system, including the use of fuzzy-logic, can be embedded in the hierarchical control system of the entire plant. Also perspective is the potential integration of the motor in the mechanical part of the system (single capsule).

\section{REFERENCES}

[1]. Бурман А.П. Управление потоками электроэнергии и повышение эффективности электроэнергетических систем:/ учебное пособие/ А.П.Бурман, Ю.К.Розанов, Ю.Г.Шакарян.- М.: Издательский дом МЭИ, 2012.-336 с.

[2]. Обухов С.Г. Системы генерирования электрической энергии с использованием возобновляемых энергоресурсов: учебное пособие: Изд-во Томского политехнического университета, 2008.- 140с.

[3]. Коломин И.В., Довгялло А.И., Русанов Ю.М., Лысенков В.В., Трубников Ю.М. Предварительные испытания роторно-лопастной машины. Вестник Самарского государственного аэрокосмического университета. №2. 2006., стр.302-305.

[4]. Плохов И.В., Донченко М.А., Лукьянов Ю.Н. Энергоэффективная автономная энергоустановка нового поколения. Доклад на международной конференции «Инновационные технологии 2009». М.:Иннотехэкспо, 2009.

[5]. Харитонов С. А. Электромагнитные процессы в системах генерирования электрической энергии для автономных объектов. - Новосибирск: Изд-во НГТУ, 2011. - 536с. 
Khitrov An., Khitrov Al. ELECTRICAL SUBSYSTEM OF THE LOW-POWER COGENERATION PLANT WITH LOW-SPEED VEHICLE

[6]. Федотов И.М., Хитров А.А. Structure designing of test stand for investigation of variable frequency electric drives. Cilvēks. Vide. Tehnoloğijas: 16 starptautiskās studentu zinātniski praktiskās konferences rakstu krājums 2012. gada 25. aprīlis. Rēzekne: 2012. - 464 lpp. p. 448-452.

[7]. Перминов А. Л., Хитров А. А., Хитров А. И. Мехатронная система «магнитоэлектрический синхронный двигатель активный выпрямитель» для автономной системы электроснабжения на базе роторно-лопастной машины с внешним подводом тепла. Труды VII Международной (VIII Всероссийской) конференции по автоматизированному электроприводу АЭП-2012: ФГБОУВПО "Ивановский государственный энергетический университет им. Ленина". - Иваново, 2012. - 708 c. c. $330-335$

[8]. Мелешин В.И., Овчинников Д.А. Управление транзисторными преобразователями электроэнергии. М. Техносфера, 2011. - 576 c. 